\title{
Amoebiasis in Active Ulcerative Colitis: Epidemiological Aspects, Association and Impact of Anti-Amoebic Therapy on Disease Severity
}

\author{
Elham Ahmed Hassan ${ }^{1 *}$, Amany Mohamed Abdel-Hamed ${ }^{1}$, Saad Zaky Mahmoud ${ }^{1}$, Mohamed EM Tolba ${ }^{2}$, Asmaa \\ Omar Ahmed ${ }^{3}$, Zainab Gaber Mahran ${ }^{1}$
}

${ }^{1}$ Gastroenterology and Tropical Medicine Department, Assiut University, Egypt

${ }^{2}$ Medical Parasitology Department, Assiut University, Egypt

${ }^{3}$ Clinical Pathology Department, Assiut University, Egypt

Submission: February 27, 2020; Published: March 11, 2020

*Corresponding author: Elham Ahmed Hassan, MD, Department of Gastroenterology and Tropical Medicine, Al-Rajhi liver center, Assiut University Hospital, Assiut 71515, Egypt

\section{Abstract}

Background and Aim: the incidence of ulcerative colitis (UC) is increasing worldwide. Several enteropathogens may be implicated in its pathogenesis. Amoebiasis is a common infection but it is overlooked or neglected especially in endemic regions. The study aimed to assess the frequency of Entamoeba (E.) histolytica in patients with active UC and evaluate the impact of the parasite and its therapy on disease severity.

Patients and Methods: Fresh fecal samples of 30 patients with active UC were examined for direct detection of E. histolytica cysts or trophozoites and its specific Ag (E. histolytica II) using ELISA. Colonoscopy and assessment of UC severity based on Mayo score and Montreal Classification were done. Patients with amoebiasis received anti-amoebic therapy and were followed up for 2 weeks.

Results: About $36.7 \%$ of those patients had amoebiasis. Amoebic infection was significantly higher in older age $(\mathrm{P}=0.048)$ and those with co-morbidities $(\mathrm{P}=0.001)$. Amoebiasis significantly associated with severe course $(\mathrm{P}=0.041, \mathrm{OR}=1.2,95 \% \mathrm{CI}: 0.2-2.1)$. Ten of eleven cases with amoebiasis had moderate/severe UC. On receiving anti-amoebic therapy, those patients showed clinical improvement with absent parasite in feces and mucosal healing in some cases.

Conclusion: Searching for amoebiasis in patients with active UC is important as it may be a trigger for UC exacerbation in endemic regions. Anti-amoebic therapy could be indicated for patients with persistent UC to avoid serious complications.

Keywords: Ulcerative colitis; Amoebiasis; E. histolytica; Exacerbation; Activity flare

Abbreviations: SD: Standard Deviation; CRP: C-Reactive Protein; UC: Ulcerative Colitis; ESR: Erythrocyte Sedimentation Rate; IGE: Infectious Gastroenteritis

\section{Introduction}

Ulcerative colitis (UC) is a chronic, idiopathic inflammatory condition of the colonic mucosa characterized by a relapsing course that often requires long-term therapy to maintain remission [1]. A complex of genetic, immune and environmental factors may be implicated in UC pathogenesis. Additionally, the possibility of enteric pathogens in initiation or reactivation of the quiescent disease had been reported [2]. Management of UC is a significant clinical challenge as its active phase is associated with bloody diarrhea with mucus simulating infectious colitis also its treatment with immunomodulators and biological agents increases the risk of opportunistic infections and exacerbates concomitant infections [3-5]. The frequency of these infections in UC patients is underestimated probably due to low index of suspicion or problems in their detection.

Amoebiasis is a common parasitic infection and globally about 50 million people are affected by Entamoeba (E.) histolytica, primarily in developing countries, with high annual fatality rate (over 100,000 deaths a year) [6,7]. It has been associated with autoimmune phenomena including antibodies to colonic epithelial cells and UC development [8]. Both amoebic colitis and UC constitute major health problems particularly in endemic areas for amoebiasis. Amoebic colitis can mimic acute phase of UC 
causing misdiagnosis or coexist with UC causing missed diagnosis [3]. Missed or misdiagnosis of amoebic infection in UC patients receiving immunosuppressive agents may cause Fulminant colitis, bowel perforation and peritonitis with a high mortality rate [9]. Furthermore, Amoebiasis can exacerbate symptoms and adversely affect the course of UC [4]. So, screening for amoebiasis is crucial in patients with UC flares for accurate diagnosis and optimal treatment.

Earlier studies assessed the frequency and participation of several enteropathogens including amoebiasis in UC flares [35], however, these studies are deficient in our region. Egypt is endemic for amoebiasis with a high prevalence of $38 \%$ and it has an increasing incidence of UC in the last years so, distinguishing UC from amoebic colitis is important $[6,7,10]$. Therefore, we aimed to assess the epidemiological aspects of amoebiasis in patients with active UC, and the impact of the parasite and its therapy on the disease severity.

\section{Patients and Methods}

\section{Study design}

This cohort study was carried out prospectively at Assiut University Hospital, Assiut, Egypt between January 2019 and June 2019. The study was approved by the Local Ethics Committee of Assiut University Hospital (The ethical approval code was 17100958) and was conducted in accordance with the previsions of the Declaration of Helsinki. Informed consent was obtained from all the participants before enrollment.

\section{Study population}

During the study period, patients with well-defined active UC admitted to Gastroenterology and Tropical Medicine Department, Assiut University Hospital, Assiut, Egypt were consecutively included in the study. The diagnosis of UC and its activity was based on clinical, colonoscopic and histopathological findings $[11,12]$, and the severity of UC activity was assessed by Mayo and Partial Mayo scores and Montreal classification [13,14]. Amoebiasis was diagnosed by the presence of the parasite and its specific antigen in stool. Patients known to have IBD other than UC or colorectal malignancies were excluded.

\section{Methods}

At study entry, thorough medical history and physical examination were taken for data collection e.g., age, sex, comorbidities, rectal bleeding, bloody diarrhea and its daily frequency and severity of disease. Laboratory investigations including complete blood picture, serum albumin, serum C-reactive protein (CRP) and erythrocyte sedimentation rate (ESR) were done. Stool analysis for the presence of E. histolytica (trophozoites and/or cysts) and for detection of E. Histolytica Ag was one. In addition, colonoscopy and assessment of Mayo score were done for all participants.

\section{Stool analysis}

With universal safety precautions and standard laboratory protocols, fresh faecal samples were collected from each patient in a dry, clean, leak-proof plastic container to be examined for $E$. histolytica. Fresh and Formol-ether concentrated stool specimens were examined as saline and Lugol's iodine wet mount to detect motile trophozites and cysts respectively. If Entamoeba parasite was identified in stool, ELISA detection of faecal E. histolytica adhesion antigen was used to confirm diagnosis using E. histolytica II assay "TechLab, Blacksburg, VA, USA" that was performed according to the manufacturer's instructions.

\section{Follow up}

Steroids were stopped for those patients with amoebic infection then they received a single oral dose of $500 \mathrm{mg}$ of Secnidazole, anti-amoebic drug, and followed by oral diloxanide furoate $(500 \mathrm{mg}$ ) three times daily for 10 days. Their response was evaluated within 2 weeks by clinical history and examination, assessment of Partial Mayo score and stool analysis for detection of the parasite and colonoscopy in some cases.

\section{Statistical analysis}

Statistical analyses were conducted using SPSS for windows version 16 (IBM Corp., Armonk, NY, USA) and Microsoft Excel 2010. The continuous data was expressed as means \pm standard deviation (SD) or median and range and was compared using Student's t test or Mann-Whitney U test. Categorical variables were expressed as a percentage and compared using chi-squared $(\chi 2)$ or Fisher's exact probability test. Multiple regression analysis was used to study the influence of independent variables on amoebic infection. Wilcoxon (two -related samples) test was used to compare the partial Mayo score in UC patients with positive E. histolytica Ag in response to anti-amoebic treatment. For all analyses, $\mathrm{P}$ value $<0.05$ is statistically significant.

\section{Results}

\section{Characteristics of the studied patients}

A total of 30 patients with active UC were consecutively included in the study between January and June 2019. Their mean age was $34 \pm 9.5$ years and $53.3 \%$ were females. The extent of disease was extensive colitis (46.7\%), left-sided colitis (36.7\%) and proctitis (16.6\%). Regarding severity of activity, 20 of the patients (66.7\%) had moderate activity, 7 (23.3\%) had mild activity, and $3(10 \%)$ had severe disease. Apart from one patient who treated with infliximab, participated patients treated with conventional treatment (5-aminosalicylic acid with or without immunotherapy) for their disease. Detailed clinical and laboratory and endoscopic findings of the studied patients were summarized in Table 1.

Table 1: Clinical, laboratory and endoscopic findings of the studied patients. 


\begin{tabular}{|c|c|c|c|c|}
\hline & $\begin{array}{l}\text { Total Patients with Active UC } \\
\qquad(n=30)\end{array}$ & $\begin{array}{l}\text { Patients without } E \text {. histolytica } \\
\qquad \mathbf{A g}(\mathrm{n}=19)\end{array}$ & $\begin{array}{l}\text { Patients with E. histolyti- } \\
\qquad \boldsymbol{c a} \mathbf{A g}(\mathrm{n}=11)\end{array}$ & $\mathbf{P}$ \\
\hline Age (years) & $34 \pm 9.5(19-52)$ & $31.4 \pm 9.2(19-52)$ & $38.5 \pm 8.8(25-51)$ & 0.048 \\
\hline $\operatorname{Sex}(M / F)$ & $14 / 16(46.7 / 53.3 \%)$ & $9 / 10(47.4 / 52.6 \%)$ & $5 / 6(45.5 / 54.5 \%)$ & 0.919 \\
\hline Smoking & $10(33.3 \%)$ & $6(31.6 \%)$ & $4(36.4 \%)$ & 0.789 \\
\hline Co-morbid diseases & $13(43.3 \%)$ & $4(21.1 \%)$ & $9(81.8 \%)$ & 0.001 \\
\hline Duration of UC disease (years) & $2.5(0-5)$ & $2(0-5)$ & $3(0-5)$ & 0.8 \\
\hline Diarrhea & $28(93.3 \%)$ & 17 (89.5\%) & $11(100 \%)$ & 0.265 \\
\hline Rectal bleeding & $23(76.7 \%)$ & $16(84.2 \%)$ & $7(63.6 \%)$ & 0.199 \\
\hline $\begin{array}{l}\text { Frequency of diarrheal attacks/ } \\
\text { day }\end{array}$ & $4(3-7)$ & $4(3-6)$ & $5(3-7)$ & 0.026 \\
\hline $\begin{array}{c}\text { Frequency of previous disease } \\
\text { attacks }\end{array}$ & $28(93.3 \%)$ & $18(94.7 \%)$ & $10(90.9 \%)$ & 0.256 \\
\hline Serum albumin (g/dl) & $3.2(2.3-3.8)$ & $3.2(2.3-3.8)$ & $3.3(2.4-3.6)$ & 0.759 \\
\hline Hemoglobin (gm/dl) & $10.8(7.8-15)$ & $11(7.8-15)$ & $10(8-14)$ & 0.981 \\
\hline Leukocyte count (x109/l) & $6.1(2.4-17)$ & $5.5(2.4-17)$ & $7(4-12)$ & 0.558 \\
\hline Platelet count (x109/l) & $276(117-579)$ & $281(117-579)$ & $270(156-412)$ & 0.53 \\
\hline ESR (1st hour) & $34(7-85)$ & $34(7-85)$ & $40(18-85)$ & 0.42 \\
\hline CRP & $32(8-108)$ & $30(8-108)$ & $34(22-62)$ & 0.471 \\
\hline \multicolumn{5}{|l|}{ Disease extension } \\
\hline $\begin{array}{l}\text { Proctitis/Left-sided/Extensive } \\
\text { colitis }\end{array}$ & $5 / 11 / 14(16.6 / 36.7 / 46.7 \%)$ & 4/9/2006 (21.1/47.4/31.7\%) & $1 / 2 / 10(9.1 / 18.2 / 72.7 \%)$ & 0.187 \\
\hline \multicolumn{5}{|l|}{ Prominent colonoscopic lesion } \\
\hline Mucosal hyperaemia & $5(16.7 \%)$ & $2(21.1 \%)$ & $1(9.1 \%)$ & \\
\hline Mucosal ulceration(s) & $19(63.3 \%)$ & $12(63.2 \%)$ & $7(63.6 \%)$ & 0.787 \\
\hline Pseudopolyps & $2(6.7 \%)$ & $1(5.3 \%)$ & $1(9.1 \%)$ & \\
\hline Mixed lesions & $4(13.3 \%)$ & $2(10.5 \%)$ & $2(10.5 \%)$ & \\
\hline Mayo score & $9(4-12)$ & $9(4-10)$ & $11(4-12)$ & 0.043 \\
\hline Partial Mayo score & $6(3-9)$ & $6(3-7)$ & $7(3-9)$ & 0.023 \\
\hline \multicolumn{5}{|l|}{ Severity of UC* } \\
\hline (Mild/Moderate/Severe) & 7/20/3 (23.3/66.7/10.0\%) & $6 / 13 / 2000(31.6 / 68.4 / 0 \%)$ & $1 / 7 / 3(9.1 / 63.6 / 27.3 \%)$ & 0.035 \\
\hline Duration of UC treatment (years) & $2(0-4)$ & $2(0-4)$ & $2(0-4)$ & 0.767 \\
\hline \multicolumn{5}{|l|}{ Treatment lines for UC } \\
\hline 5-ASA & $7(23.3 \%)$ & $6(31.6 \%)$ & $1(9.1 \%)$ & \\
\hline 5-ASA and steroid & $19(63.3)$ & $11(57.9 \%)$ & $8(72.7 \%)$ & 0.322 \\
\hline 5-ASA, steroid and azathioprine & $3(10 \%)$ & $2(10.5 \%)$ & $1(9.1 \%)$ & \\
\hline Infliximab & $1(3.3 \%)$ & 0 & $1(9.1 \%)$ & \\
\hline
\end{tabular}

Values were presented as mean \pm standard deviation, median and range or $\mathrm{n}(\%)$. P value $<0.05$ means significant.

CRP: C-Reactive Protein; ESR: Erythrocyte Sedimentation Rate; UC: Ulcerative Colitis

\section{Diagnosis of amoebic infection}

On fecal examination, amoebic infection was identified in $36.7 \%$ of patients ( 6 females and 5 males with mean age of 38.5 \pm 8.8 years), where, trophozites were detected in two cases, cysts in seven cases and both trophozites and cysts in further two cases. Furthermore, the presence of E. histolytica was confirmed with fecal detection of its specific Ag in these cases. Details of characteristics of ulcerative colitis patients with E. histolytica Ag were shown in Table 2. 
Table 2: Details of characteristics of ulcerative colitis patients with E. histolytica Ag.

\begin{tabular}{|c|c|c|c|c|c|c|c|c|c|c|c|c|c|c|}
\hline \multirow[t]{2}{*}{ No } & \multirow[t]{2}{*}{ Age } & \multirow[t]{2}{*}{ Sex } & \multirow[t]{2}{*}{ Smoking } & \multirow[t]{2}{*}{$\begin{array}{c}\text { Disease } \\
\text { Duration } \\
\text { (years) }\end{array}$} & \multirow[t]{2}{*}{$\begin{array}{l}\text { Co-mor- } \\
\text { bid } \\
\text { diseases }\end{array}$} & \multirow[t]{2}{*}{$\begin{array}{l}\text { Blood } \\
\text { in stool }\end{array}$} & \multirow[t]{2}{*}{$\begin{array}{l}\text { Mayo } \\
\text { score }\end{array}$} & \multirow[t]{2}{*}{$\begin{array}{l}\text { Partial } \\
\text { Mayo } \\
\text { score }\end{array}$} & \multirow[t]{2}{*}{$\begin{array}{l}\text { Treat- } \\
\text { ment }\end{array}$} & \multirow[t]{2}{*}{$\begin{array}{l}\text { E. histo- } \\
\text { lytica in } \\
\text { stool }\end{array}$} & \multicolumn{2}{|c|}{$\begin{array}{c}\text { Colonoscopic Fea- } \\
\text { tures }\end{array}$} & \multirow{2}{*}{$\begin{array}{c}\text { Response } \\
\text { to An- } \\
\text { ti-Amoebic } \\
\text { TTT * }\end{array}$} & \multirow{2}{*}{$\begin{array}{c}\text { Post An- } \\
\text { ti-Amoebic } \\
\text { Treatment } \\
\text { Partial Mayo } \\
\text { score }\end{array}$} \\
\hline & & & & & & & & & & & $\begin{array}{l}\text { Extension } \\
\text { site }\end{array}$ & $\begin{array}{l}\text { Prom- } \\
\text { inent } \\
\text { lesion }\end{array}$ & & \\
\hline 1 & 48 & M2 & Yes & 5 & CLD & Yes & 12 & 9 & $\begin{array}{l}\text { 5-ASA } \\
\text { Ste- } \\
\text { roid }\end{array}$ & Cyst & Pancolitis & Mixed & Yes & 6 \\
\hline 2 & 28 & M & Yes & 3 & CLD & Yes & 11 & 8 & $\begin{array}{l}\text { 5-ASA } \\
\text { Ste- } \\
\text { roid }\end{array}$ & both & $\begin{array}{l}\text { Extensive } \\
\text { colitis }\end{array}$ & $\begin{array}{l}\text { Ulcer- } \\
\text { ation }\end{array}$ & Yes & 5 \\
\hline 3 & 39 & $\mathrm{~F}$ & No & 3 & DM & Yes & 11 & 8 & $\begin{array}{l}\text { 5-ASA } \\
\text { Ste- } \\
\text { roid }\end{array}$ & both & $\begin{array}{l}\text { Extensive } \\
\text { colitis }\end{array}$ & $\begin{array}{l}\text { Pseu- } \\
\text { do-pol- } \\
\text { yps }\end{array}$ & Yes & 5 \\
\hline 4 & 36 & M & Yes & 2 & No & Yes & 10 & 7 & $\begin{array}{l}\text { 5-ASA } \\
\text { Ste- } \\
\text { roid }\end{array}$ & Cyst & $\begin{array}{l}\text { Extensive } \\
\text { colitis }\end{array}$ & $\begin{array}{l}\text { Ulcer- } \\
\text { ation }\end{array}$ & Yes & 4 \\
\hline 5 & 37 & M & Yes & 2 & Cardiac & No & 4 & 3 & 5-ASA & $\begin{array}{c}\text { Tro- } \\
\text { phozite }\end{array}$ & Proctitis & $\begin{array}{l}\text { Hyper- } \\
\text { aemia }\end{array}$ & Yes & 2 \\
\hline 6 & 28 & F & No & 3 & No & No & 11 & 8 & $\begin{array}{l}\text { 5-ASA } \\
\text { Ste- } \\
\text { roid }\end{array}$ & $\begin{array}{l}\text { Tro- } \\
\text { phozite }\end{array}$ & $\begin{array}{l}\text { Lt sided } \\
\text { colitis }\end{array}$ & $\begin{array}{l}\text { Ulcer- } \\
\text { ation }\end{array}$ & Yes & 5 \\
\hline 7 & 41 & F & No & 5 & DM & No & 12 & 9 & $\begin{array}{l}\text { 5-ASA } \\
\text { Ste- } \\
\text { roid } \\
\text { Aza- } \\
\text { thio- } \\
\text { prine }\end{array}$ & Cyst & $\begin{array}{l}\text { Extensive } \\
\text { colitis }\end{array}$ & $\begin{array}{l}\text { Ulcer- } \\
\text { ation }\end{array}$ & Yes & 6 \\
\hline 8 & 51 & F & No & 1 & $\begin{array}{c}\text { DM, } \\
\text { cardiac }\end{array}$ & Yes & 8 & 5 & $\begin{array}{l}5 \text { ASA } \\
\text { Ste- } \\
\text { roid }\end{array}$ & Cyst & $\begin{array}{l}\text { Lt sided } \\
\text { colitis }\end{array}$ & Mixed & Yes & 3 \\
\hline 9 & 48 & F & No & 3 & Renal & No & 9 & 6 & $\begin{array}{l}\text { 5-ASA } \\
\text { Ste- } \\
\text { roid }\end{array}$ & Cyst & $\begin{array}{l}\text { Extensive } \\
\text { colitis }\end{array}$ & $\begin{array}{l}\text { Ulcer- } \\
\text { ation }\end{array}$ & Yes & 3 \\
\hline 10 & 25 & M & No & 0 & CLD & No & 12 & 9 & $\begin{array}{l}\text { Inflix- } \\
\text { imab }\end{array}$ & Cyst & $\begin{array}{l}\text { Extensive } \\
\text { colitis }\end{array}$ & $\begin{array}{l}\text { Ulcer- } \\
\text { ation }\end{array}$ & Yes & 7 \\
\hline 11 & 42 & $\mathrm{~F}$ & No & 2 & Cardiac & No & 8 & 5 & $\begin{array}{l}\text { 5-ASA } \\
\text { Ste- } \\
\text { roid }\end{array}$ & Cyst & $\begin{array}{l}\text { Extensive } \\
\text { colitis }\end{array}$ & $\begin{array}{l}\text { Ulcer- } \\
\text { ation }\end{array}$ & Yes & 3 \\
\hline
\end{tabular}

*Anti-amoebic treatment by secnidazole $500 \mathrm{mg}$ (4 tablets a single oral dose) and response to treatment in the form of clinical improvement and absence of parasite in stool

CLD: Chronic Liver Disease; DM: Diabetes Mellitus; HTN: Hypertension; 5-ASA: 5-Aminosalicylicacid

\section{Comparison between patients with and without amoebic infections}

Compared to those without amoebiasis, patients with amoebiasis were significantly older age where $45.5 \%$ of these cases were older than 40 years. In addition, co-morbidities, frequency of diarrheal attacks per day, severity of the disease based on Montreal classification, Mayo and partial Mayo scores were significantly higher in patients with amoebic infection compared to those without infection. However, gender and other clinical and laboratory parameters had no significant differences between two groups (Table 1).

\section{Association between severity of ulcerative colitis and amoebic infection}

The presence of amoebiasis was significantly associated with moderate/severe UC (0.041). Ten out of eleven cases (90.9\%) with E. histolytica had moderate/severe UC, while 13 out of 19 cases (68.4\%) without E. histolytica had moderate/severe UC (Table 3). Detection of E. histolytica in stool was associated with a relative risk for moderate/severe UC of 1.2 (95\% CI: 0.2 to 2.1) compared to patients without detectable E. histolytica. 
Table 3: Association between severity of ulcerative colitis and amoebic infection.

\begin{tabular}{|c|c|c|c|}
\hline E. histolytica & Active Ulcerative colitis & Mild (n=7) \\
& Severe/moderate (n= 23) & $1(9.1 \%)$ & \\
Yes (n=11) & $10(90.9 \%)$ & $6(76.7 \%)$ & 0.041 \\
No $(\mathrm{n}=19)$ & $13(68.4 \%)$ & \\
\hline
\end{tabular}

\section{Follow-up ulcerative colitis patients with amoebic infection}

On receiving the anti-amoebic therapy, those patients clinically improved e.g., decrease the frequency of daily diarrheal attacks, decrease blood amount in stool, improved their general condition and absence of fecal parasite with colonoscopic mucosal healing in some cases (Figure 1). In addition, those patients receiving anti-amoebic treatment showed significant improvement in their partial Mayo scores [pre-treatment score 7 (3 - 9) vs. posttreatment 5 (2 -7), $\mathrm{P}<0.001$ ] as shown in Figure 2.

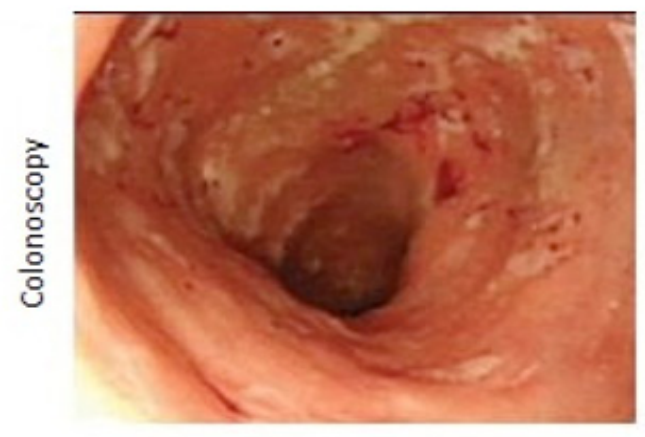

a) Before anti-amoebic therapy (hyperemic mucosa with ulcerations)

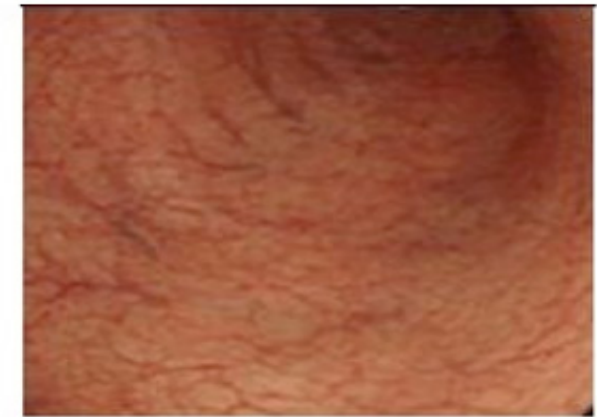

b) After anti-amoebic therapy (mucosal healing with disappearance of ulcerations)

Figure 1: Colonoscopic findings of a patient with ulcerative colitis and positive stool E. histolytica Ag a) before anti-amoebic therapy (hyperemic mucosa with ulcerations) b) after anti-amoebic therapy (mucosal healing disappearance of ulcerations).

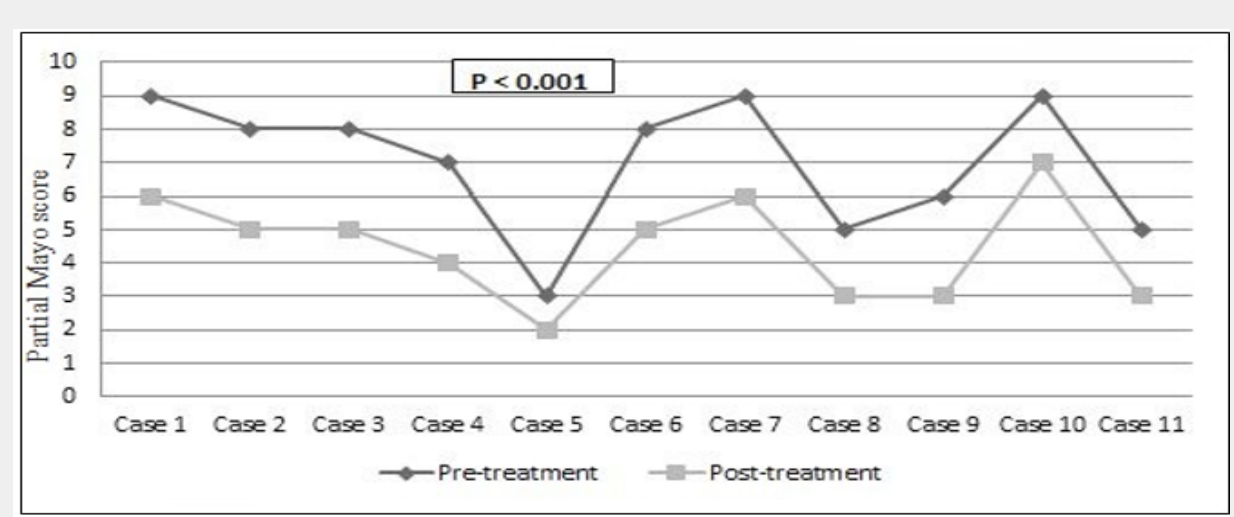

Figure 2: Response to anti-amoebic therapy in ulcerative colitis patients with amoebiasis.

\section{Discussion}

This study aimed to highlight the epidemiological aspects of amoebiasis in patients with active UC, and the impact of the parasite and its therapy on disease severity. Egypt has a high prevalence of amoebic infection [4,7], and a limited published data on amoebiasis and its relation to UC activity coexist so, it was encouraged to be carried out on that special population. Infection may contribute in the ethiopathogenesis of UC affecting the colonic mucosa with disarrangement in its immunity [9]. Amoebic infection is usually overlooked or underestimated due 
to diverse clinical and colonoscopic presentations of amoebic colitis confusing with other types of colitis including UC in addition to difficulty in its definitive diagnosis with absence of fecal trophozoites and cysts in some cases [4,15]. Detection of $E$. histolytica by identifying both the parasite and its specific Ag in stool, as in our cases, supports the diagnostic utility and enhances the sensitivity to definite detection of amoebic infection [15]. Our analysis identified amoebiasis in $36.7 \%$ of thirty patients with active UC. Our result was higher than that mentioned in previous studies in Mexico (5\%), Turkey (17.2\%), and Bosnia and Herzegovina (14.3\%) owing to its endemicity in our area along with various environmental and socioeconomic factors [5].

This study corroborates that age, co-morbidities and disease severity were independently associated with amoebiasis in those patients that were in agreement with previous studies [16-18]. We found that UC patients with amoebiasis were significantly older than those without, where $45.5 \%$ of cases were over 40 years old because of their poor health and higher frequency of comorbidities that increased their susceptibility to infection. These findings were consistent with earlier reports that showed that the peak rate of amoebiasis occurred between 40 and 49 years [17]. In line with previous studies $[4,19]$, in those UC patients, amoebiasis were significantly associated with severe course that can be explained by mucosal disruption facilitating mucosal invasion of trophozoites and worsening the clinical and endoscopic conditions [16]. Babic et al., [4] documented that hyperactivity of the mucosal immune system to the intraluminal antigens e.g., E. histolytica can initiate or reactivate quiescent disease in IBD. Schulzke et al., [20] reported that infectious gastroenteritis (IGE) may exacerbate IBD increasing its risk (OR=1.40,95\% CI: 1.19 - 1.66). In addition, the increased use of immunomodulators and biological agents can increase the risk of enteropathogens including amoebiasis among those patients [4]. These data indicate that stools from UC patients should be examined before planning optimal medical therapy. Contrary to our finding, Vukobrat-Bijedic et al., [18] found that disease severity was not associated with amoebic infection in UC patients.

Consistent with the earlier series [21-23], in this study, treatment of infected patients with anti-amoebic therapy showed symptomatic improvement and colonic mucosal healing in some cases. Collins and Bynum [21], treated four UC patients with amoebiasis by medications for both diseases and observed a good response. However, Brown \& Winkelman [22], treated two UC patients with amoebiasis with anti-amoebic therapy resulting in clinical and endoscopic improvement with abolition of colectomy decision in one of those two patients. Underwood [24] and Shirley \& Moonah [25] concluded that this concomitant amoebiasis should always be considered before administrating corticosteroids and/or immunosuppressive therapy especially in UC patients residing in endemic areas or with a travel history. Therefore, an empirical trial of anti-amoebic therapy should be recommended in persistent or relapsing IBD, especially in endemic areas that may reduce or prevent serious complications or unneeded critical management as colectomy. In this study, secnidazole was administrated in a single oral dose that was better tolerated with a high cure rate making it a suitable option to other single-dose treatments and an attractive alternative to multiple dose regimens with other drugs in this class [15,26]. This study has certain strengths and limitations. This is one of the very few studies that have searched for amoebic infection as a trigger for UC exacerbations and the effect of its treatment on disease severity in this endemic area where the majority of previous studies discussed amoebiasis in patients who lived in developed countries and had a travel history. In addition, amoebic infection was diagnosed by detecting the parasite and its specific Ag in stool to differentiate it from non-pathogenic organisms e.g., E. dispar or E. moshkovskiis and to distinguish new from past infection in our region where seroprevalence is high. Single dose of antiamoebic drug "secnidazole" was highly effective and tolerated in those patients who were exhausted by frequent medications. On the other hand, there were some limitations to this work. It was a small sample sized and single-centre study however, it carried out in Assiut University Hospital; a tertiary care centre, where cases of persistent or relapsing UC is more possible to be admitted. Colonoscopic mucosal biopsies for detection of the parasite were not taken for fear of perforation during air insufflations to expand the colon in those patients with UC flares. So, large multicenter cohort studies will be emphasized to confirm these findings.

\section{Conclusion}

Intestinal amoebiasis was presented in $36.7 \%$ of patients with active UC that may contribute to in its activity flare or persistence despite optimal medical treatment of UC. Searching for E. histolytica is recommended in every patient with UC to rule out missed or misdiagnosis. A trial of anti-amoebic therapy may be indicated for any patient with persistent UC to avoid serious complications.

\section{References}

1. Matsuoka K, Kobayashi T, Ueno F, Matsui T, Hirai F, et al. (2018) Evidence-based clinical practice guidelines for inflammatory bowel disease. J Gastroenterol 53(3): 305-353.

2. Mylonaki M, Langmead L, Pantes A, Johnson F, Rampton DS, et al. (2004) Enteric infection in relapse of inflammatory bowel disease: importance of microbiological examination of stool. Eur J Gastroenterol Hepatol 16(8): 775-778.

3. Weng M, Wei S, Leong Y, Tung C, Shun C, et al. (2016) Amebic and cytomegalovirus colitis mimic ulcerative colitis. Advances in Digestive Medicine 3(2): 65-68.

4. Babic E, Bevanda M, Mimica M, Karin M, Volaric M, et al. (2016) Prevalence of amebiasis in inflammatory bowel disease in University Clinical Hospital Mostar. Springer plus 5(1): 1586.

5. Yamamoto Furusho JK, Torijano Carrera E (2010) Intestinal Protozoa Infections among Patients with Ulcerative Colitis: Prevalence and Impact on Clinical Disease Course. Digestion 82(1): 18-23.

6. Stauffer W, Abd Alla M, Ravdin JI (2006) Prevalence and incidence of Entamoeba histolytica infection in South Africa and Egypt. Arch Med Res 37(2): 266-269. 
7. Stanley SL Jr (2003) Ambiasis. lancet 361(9362): 1025-1034.

8. Andersen PL (2002) Amebiasis. Ugeskr Laeger 162(11): 1537-1541.

9. Toh Yoon EW, Sumii M (2016) Severe amoebic colitis in an HIV-infected male patient. BMJ Case Rep: bcr2016218570.

10. Esmat S, El Nady M, Elfekki M, Elsherif Y, Naga M, et al. (2014) Epidemiological and clinical characteristics of inflammatory bowel diseases in Cairo, Egypt. World J Gastroenterol 20(3): 814-821.

11. Ordas I, Eckmann L, Talamini M, Baumgart DC, Sandborn WJ, et al. (2012) Ulcerative colitis. Lancet 380(9853): 1606-1619.

12. Schoepfer AM, Beglinger C, Straumann A, Trummler M, Renzulli P, et al (2009) Ulcerative Colitis: Correlation of the Rachmilewitz Endoscopic Activity Index with Fecal Calprotectin, Clinical Activity, C reactive Protein, and Blood Leukocytes. Inflamm Bowel Dis 15(12): 1851-1858.

13. Rutgeerts P, Sandborn WJ, Feagan BG, Reinisch W, Olson A, et al. (2005) Infliximab for induction and maintenance therapy for ulcerative colitis. N Engl J Med 353(23): 2462-2476.

14. Silverberg MS, Satsangi J, Ahmad T, Arnott ID, Bernstein CN, et al (2005) Toward an integrated clinical, molecular and serological classification of inflammatory bowel disease: Report of a Working Party of the 2005 Montreal World Congress of Gastroenterology. Can J Gastroenterol 19(Suppl A): 5-36.

15. Roure S, Valerio L, Soldevila L, Salvador F, Fernandez-Rivas G, et al (2019) Approach to amoebic colitis: Epidemiological, clinical and diagnostic considerations in a non-endemic context (Barcelona, 20072017). PLoS One 14(2): e0212791.

16. Mhlanga BR, Lanoie LO, Norris HJ, Lack EE (1992) Amebiasis complicating carcino mas: a diagnostic dilemma. Am J Trop Med Hyg 46(6): 759-764.
17. Monthly Infectious Disease Surveillance Report (2015) Public Health Ontario.

18. Vukobrat Bijedic Z, Husic Selimovic A, Bijedic N, Bjelogrlic I, Djuran A, et al. (2013) Intestinal amebiasis in a group of patients with ulcerative colitis: influence on clinical course of the disease. Med Arch 67(1): 1012.

19. Vucelic B (2002) Upalne bolesti crijeva U: Vucelic B i sur (ured) Gastroenterologija i hepatologija Zagreb: Medicinska naklada 723760.

20. Schulzke JD, Ploeger S, Amasheh M, Fromm A, Zeissig S, et al. (2009) Epithelial tight junctions in intestinal inflammation. Ann NY Acad Sci 1165: 294-300.

21. Collins EN, Bynum FL (1948) Amoebiasis and indeterminate ulcerative colitis; combined therapy as applied to veterans from overseas. Med Clin North Am 32: 408-418.

22. Brown CH, Winkelman EI (1965) Amoebiasis and ulcerative colitis. Cleveland Clinic Quarterly 32: 61-67.

23. Evangelopoulos A, Legakis N, Vakalis N (2001) Microscopy, PCR and ELISA applied to the epidemiology of amoebiasis in Greece. Parasitol Int 50(3): 185-189.

24. Underwood JCE (2004) General and Systematic Pathology. (4 ${ }^{\text {th }}$ edn.), Edinburgh Churchill Livingstone, pp. 370-374.

25. Shirley DA, Moonah S (2016) Fulminant amebic colitis after corticosteroid therapy: a systematic review. PLoS Negl Trop Dis 10(7): e0004879.

26. Gillis JC, Wiseman LR. Secnidazole (1996) A review of its antimicrobial activity, pharmacokinetic properties and therapeutic use in the management of protozoal infections and bacterial vaginosis. Drugs 51(4): 621-638. 